\title{
Peningkatan Kemampuan Aparatur Desa Dalam Tata Kelola Administrasi Pemerintahan Desa Pada Desa Mendalo Indah
}

\author{
Wiralestari, Iskandar Sam, Lutfi, Dewi Fitriani, Widya Sari Wendry \\ Fakultas Ekonomi dan Bisnis Universitas Jambi, Indonesia
}

\begin{abstract}
ABSTRAK
Pengabdian Kepada Masyakat ini berjudul PPM: Peningkatan Kemampuan Aparatur Desa Dalam Tata Kelola Administrasi Pemerintahan Desa. Pengabdian ini dilakukan di Desa Mendalo Indah yangmana memiliki sistem administrasi yang belum tertib dan lengkap. Sistem administrasi desa belum sesuai dan memenuhi kriteria yang tertuang dalam Peraturan Menteri Dalam Negeri Nomor 47 Tahun 2016 Tentang Administrasi Pemerintahan Desa. Hal ini dikarenakan kurangnya sosialisasi dan pelatihan mengenai pedoman administrasi pemerintahan desa kepada aparatur desa. Selain itu, aparatur desa yang tidak melakukan upgrade pengetahuan mereka mengenai sistem administrasi pemerintahan terbaru. Untuk itu diperlukan suatu penyuluhan dan pelatihan mengenai sistem administrasi desa yang sesuai dengan peraturan
\end{abstract}

Kata Kunci : Aparatur Desa, Sistem Administrasi Desa.

\section{PENDAHULUAN}

\section{Latar Belakang}

Pemerintah Indonesia memiliki fokus utama dalam pembangunan yaitu pembangun desa, dikarenakan banyak penduduk Indonesia yang tinggal di pedesaan dan hampir $80 \%$ penduduk Indonesia berada di pedesaan (Atika et al, 2017). Berdasarkan data BPS (2018) jumlah desa di Indonesia berjumlah 75.436 desa.

Peraturan Menteri desa. Pembangunan Daerah Tertinggal dan Transmigrasi Nomor 2 Tahun 2016, membagi desa berdasarkan tingkat pembangunan desa yangmana diukur dengan menggunakan Indeks Desa Membangun (IDM), yaitu: Desa Mandiri atau dikenal dengan Desa Sembada merupakan desa yang maju yangmana dapat membangun desanya sendiri dengan memanfaatkan potensi yang ada di desanya, hal ini dapat dilihat dari masyarakatnya yang sejahtera. Desa Maju dikenal dengan Desa Pra sembada yang mana desa ini memiliki kategori yang hampir sama dengan desa mandiri. Desa ini mememiliki potensi desa dan dapat mengelolanya dengan baik serta mampu mengurangi jumlah masyarakat miskin di desanya. Desa Berkembang dikenal dengan Desa Madya yaitu desa yang memiliki potensi desa yang potensial namun belum dapat mengelolanya dengan baik. Desa Tertinggal yangmana disebut sebagai Desa Pra Madya adalah desa yang belum atau tidak dapat mengelola potensi yang ada di desanya dan masyarakatnya banyak ditemukan masih dalam keadaan miskin. Terakhir Desa Sangat Tertinggal yangmana dikenal dengan Desa Pratama yaitu desa yang sama sekali tidak mempunyai kesiapan dalam menghadapi bencana alam, perubahan ekonomi dan sering kali ditemukan adanya konflik sosial serta tidak memiliki kemampuan dalam menggali dan mengelola potensi desa, sehingga mayoritas masyaratakatnya miskin. 
Berdasarkan Undang-undang Nomor 6 Tahun 2014 menyatakan tujuan utama Pemerintah Indonesia dalam pembangunan desa yaitu membangun desa yang mandiri atau desa otonom. Desa diberikan kesempatan serta peluang dalam mengelola dan mengatur sumber potensial yang ada di desanya dan memberdayakan masyarakatnya menjadi mandiri (Undang-undang Nomor 32 Tahun 2004). Desa mandiri dapat terwujud jika ada penerapan sistem perencanaan anggaran, penyusunan anggaran dan pelaksanaan serta pengawasan anggaran yang efektif, efisien dan optimal (Kurniawan, 2015). Untuk itu diperlukan suatu sistem administrasi yang tertib sebagai basis data desa dan informasi tentang desa (Alkhadafi, et al 2019).

Sistem administrasi akan berjalan tertib apabila pelaksanaan tata kelola pemerintahan desa dilaksanakan dengan baik. Hal ini dapat terlihat dari adanya komitmen aparatur desa. Keberhasilan ini dimulai dari adanya penyusunan perencanaan desa yang baik yang didukung dari data dan informasi yang akurat sehingga menghasilkan sistem administrasi yang tertib dan lengkap (Permendagri No. 81 Tahun 2015). Ketertiban sistem administrasi dimulai dari tersedianya buku administrasi desa yang meliputi buku administrasi umum, kependudukan, pembangunan dan sebagainya.

Mitra pengabdian ini adalah desa Mendalo Indah kecamatan Jaluko. Dengan kepala desa bernama Muslim, SE. Desa ini terletak di kabubaten Muaro Jambi Provinsi Jambi dengan memiliki jarak dari Universitas Jambi (lokasi tim pengabdian) berjarak sekitar $1 \mathrm{~km}$.

Berdasarkan pengamatan pendahuluan yang dilakukan oleh tim pengabdian, diperoleh informasi bahwa desa Mendalo Indah memiliki sistem administrasi yang belum tertib dan lengkap. Sistem administrasi desa belum sesuai dan memenuhi kriteria yang tertuang dalam Peraturan Menteri Dalam Negeri Nomor 47 Tahun 2016 Tentang Administrasi Pemerintahan Desa. Hal ini dikarenakan kurangnya sosialisasi dan pelatihan mengenai pedoman administrasi pemerintahan desa kepada aparatur desa. Selain itu, aparatur desa yang tidak melakukan upgrade pengetahuan mereka mengenai sistem administrasi pemerintahan terbaru.

Permasalahan ini juga dikuatkan dengan yang diutarakan oleh Budi Hartono (2019) yang menyatakan bahwa dari 140 desa di Muarojambi ditemukan penyimpangan dana desa di 32 desa yang mana penyimpangan terjadi terkait dengan sistem administrasi desa. Penyimpangan sistem administrasi dana desa banyak terjadi pada kasus penunggakan pajak. Hal ini dikarenakan ketidaktahuan dari aparatur desa.

\section{Permasalahan Mitra}

Berdasarkan penjelasan sebelumnya, dapat disimpulkan bahwa permasalahan mitra yang perlu diatasi pada mitra pengabdian desa Mendalo Indah meliputi:

1. Kurangnya pengetahuan dan pemahaman aparatur desa mengenai sistem administrasi desa.

2. Kurangnya kesadaran aparatur desa akan pentingnya sistem administrasi desa.

3. Buku administrasi desa yang tidak lengkap.

4. Belum maksimalnya penggunaan teknologi informasi yangmana seharusnya merupakan sebagai pendukung dalam sistem administrasi desa.

\section{TINJAUAN LITERATUR}

Penyelenggaraan pemerintahan desa dapat dikatakan berhasil dapat dilihat dari perencanaan desa. Perencanaan desa dapat berhasil jika didukung dengan informasi yang memadai. 
Informasi yang memadai ditandai dengan adanya sistem administrasi yang dikelola dengan baik maupun efektif. Permendagri no.47 tahun 2016 mendefinisikan administrasi desa dapat dikatan sebagai suatu siklus proses dalam penyelengaaran kegiatan dan pembangunan desa dengan mengunakan kemampuan apparat desa dalam mencapai tujuan yang telah ditetapkan. Tujuan tersebut adalah mewujudkan peningkatan dalam partisipasi jalannya pemerintahan, pembangunan, dan penyelenggaraan sistem administrasi yang baik dan efektif. Dengan kata lain administrasi desa adalah seperangkat proses dalam pencatatan dan penginformasian tentang desa secara keseluruhan yang tercantum dalam buku administrasi desa.

Dalam Permendagri no 47 tahun 2016, sistem administrasi desa dapat dikelompokkan menjadi beberapa kelompok, antara lain :

1) Administrasi Umum adalah pencatatan data dan informasi mengenai kegiatan pemerintahan Desa pada Buku Administrasi Umum. Buku ini register sebagai berikut:

a. Buku Peraturan Di Desa;

b. Buku Keputusan Kepala Desa;

c. Buku Inventaris dan Kekayaan Desa;

d. Buku Aparat Pemerintah Desa;

e. Buku Tanah Kas Desa;

f. Buku Tanah di Desa;

g. Buku Agenda;

h. Buku Ekspedisi; dan

i. Buku Lembaran Desa dan Buku Berita Desa.

2) Administrasi Penduduk adalah kegiatan pencatatan data dan informasi mengenai kependudukan pada Buku Administrasi Penduduk. Buku ini terdiri dari register sebagai berikut:

a. Buku Induk Penduduk;

b. Buku Mutasi Penduduk Desa;

c. Buku Rekapitulasi Jumlah Penduduk;

d. Buku Penduduk Sementara; dan

e. Buku Kartu Tanda Penduduk dan Buku Kartu Keluarga

3) Administrasi Keuangan adalah kegiatan pencatatan data dan informasi mengenai pengelolaan keuangan Desa pada Buku Administrasi Keuangan. Soleh dan Romansyah (2015:3) mendefinisikan keuangan desa sebagai semua hak dan kewajiban Indonesia yang dapat di nilai dengan uang serta segala sesuatu baik berupa benda maupun berupa barang yang dapat dijadikan milik desa berhubungan dengan pelaksanaan hak dan kewajiban tersebut. oleh sebab itu keuangan desa harus di administrasikan dengan baik dan teratur. Buku ini terdiri dari register sebagai berikut:
a. Buku APB Desa;
b. Buku Rencana Anggaran Biaya;
c. Buku Kas Pembantu Kegiatan;
d. Buku Kas Umum;
e. Buku Kas Pembantu; dan
f. Buku Bank Desa

4) Administrasi Pembangunan adalah kegiatan pencatatan data dan informasi pelaksanaan pembangunan dan pemberdayaan masyarakat pada Buku Administrasi Pembangunan, Buku ini terdiri dari register sebagai berikut:

a. Buku Kegiatan Pembangunan; 
b. Buku Inventarisasi Hasil-hasil Pembangunan; dan

c. Buku Kader Pendampingan dan Pemberdayaan Masyarakat

5) Administrasi Lainnya. Buku ini terdiri dari register sebagai berikut:

a. Kegiatan Badan Permusyawaratan Desa dalam buku administrasi Badan Permusyawaratan Desa;

b. Kegiatan musyawarah Desa dalam buku musyawarah Desa; dan

c. Kegiatan Lembaga Kemasyarakatan Desa/Lembaga Adat dalam buku Lembaga Kemasyarakatan Desa/Lembaga Adat.

Dengan menjalankan tata kelola administrasi yang baik dan efektif dapat menciptakan tata kelola pemerintahan yang baik secara efektif. Keefektifan tata kelola pemerintahan yang baik dapat dilihat dari berjalannya penerapan prinsip-prinsip tata kelola yaitu transparansi, akuntabilitas, responsibilitas, independensi dan kesetaraan atau kewajaran (Daniri, 2014).

\section{METODE PELAKSANAAN}

Dalam melaksanakan pengabdian pada masyarakat, tim pengabdian akan menggunakan beberapa metode. Metode yang dilakukan terdiri dari metode pemaparan materi, kemudian dilanjut dengan metode pemberian contoh dan metode tanya jawab. Adapun tahapan metode pengabdian masyarakat ini dapat di jelaskan sebagai berikut:

1) Tahapan pertama, metode pemaparan materi

Pada tahapan ini dilakukan memaparkan materi yang bersifat teori/ konseptual tentang sistem administrasi desa, hal ini dilakukan untuk memberikan pengetahuan kepada aparatur desa.

2) Tahapan kedua, metode pemberian contoh

Setelah memaparkan materi, tahapan selanjutnya adalah memberikan contoh dalam melaksanakan administrasi desa.

3) Tahapan ketiga, tanya jawab

Tahapan ini adalah tahapan dimana mitra diberikan kesempatan untuk mengkonfirmasi secara lebih delam terkait materi yang telah disampaikan.

\section{HASIL DAN PEMBAHASAN}

Kegiatan pengabdian pada masyarakat ini dilaksanakan 1 (satu) hari yaitu pada hari Rabu tanggal 29 Juli 2020 bertempat di Kantor Kepala Desa Mendalo Indah. Adapun kegiatan pelatihan selama 1 hari tersebut dapat diuraikan sebagai berikut ini : Pelaksanaan pelatihan dilakukan dalam suasana santai dan informal selama 1 hari Kegiatan pengabdian ini dimulai pada pukul 09.00 wib dengan pemberian materi yang berhubungan dengan administrasi desa yang sesuai dengan Permendagri no 47 tahun 2016 tentang administrasi desa. Kegiatan pengabdian ini dihadiri oleh kepala desa Mendalo Indah Bapak Muslim, SE dan 17 orang aparatur desa. Dalam kegiatan ini tidak hanya memberikan materi dalam bentuk presentasi, namun juga memberikan contoh pengisisan informasi desa ke dalam buku register desa yang sesuai dengan format Permendagri no 47 tahun 2016. Mayoritas peserta berpartisipasi dengan aktif dan penuh antusias, hal ini dapat dilihat banyaknya peserta yang mengajukan pertanyaan mengenai administrasi desa. Para aparatur desa sangat senang dengan adanya kegiatan pengabdian ini. Kegiatan ini memberikan pemahaman dan pengetahuan para aparatur desa tentang administrasi Desa. 


\section{KESIMPULAN DAN SARAN}

Kegiatan pengabdian kepada masyarakat ini dapat disimpulkan bahwa sekitar $80 \%$ peserta yang merupakan aparatur desa memahami dan mampu meyusun buku register administrasi desa. Kegiatan pengabdian ini sangat diperlukan dilaksanakan kepada desa-desa lainnya. Kegiatan ini memberikan pengaruh yang baik kepada aparatur desa, dikarenak dengan adanya kegiatan ini dapat meningkatkan motivasi para aparatur desa dalam meningkatkan pemahaman, pengetahuan dan kemampuan mereka dalam sistem administrasi desa. Sistem administrasi desa yang baik dan efektif menunjukkan berjalannya tata kelola pemerintahan yang baik dan efektif. Sehingga, hal ini akan menghasilkan meningkatnya kualitas pelayanan public dalam hal pemberian informasi desa yang akurat dan jelas.

\section{DAFTAR PUSTAKA}

Alkadafi, Muammar, Rusdi, \& Muhammad April. 2019. Penataan Administrasi Pemerintahan Desa Di Desa Kualu Nenas Kecamatan Tambang Kabupaten Kampar. Dinamisia Jurnal Pengabdian Kepada Masyarakat Vol. 3, Special Issue Juni 2019, Hal. 76-84.

Atika, Brima Dewi, Ita Prihantika, \& Rahayu Sulistiowati. 2018. Peningkatan Kapasitas Perangkat Desa dalam Penyusunan Laporan Keuangan Desa se-Kecamatan Buay Bahuga Kabupaten Way Kanan. Prosiding Seminar Nasional Penerapan IPTEKS Politeknik Negeri Lampung 08 Oktober 2018 ISBN 978-602-5730-68-9 halaman 178183 .

Budi Hartono, selaku Kepala Inspektorat Kabupaten Muarojambi. 2019. Pengelolaan Dana Desa di Muarojambi Banyak Menyimpang. Melalui https://www.beritasatu.com/nasional/563153-pengelolaan-dana-desa-di-muarojambibanyak-menyimpang. Diakses pada tanggal 8/4/2020.

Daniri, Mas Achmad. 2014. Lead by GCG. Jakarta: Gagas Bisnis.

Kurniawan Borni, 2015, Desa Mandiri, Desa Membangun, Kementerian Desa Pembangunan Daerah Tertinggal dan Transmigrasi Republik Indonesia, Jakarta.

Peraturan Menteri Dalam Negeri Republik Indonesia Nomor 47 Tahun 2016 Tahun Tentang Administrasi Pemerintahan Desa.

Peraturan Menteri Desa, Pembangunan Daerah Tertinggal, Dan Transmigrasi Republik Indonesia Nomor 2 Tahun 2016 Tentang Indeks Desa Membangun.

Undang-Undang Nomor 32 Tahun 2004 Tentang Pemerintahan Daerah

Undang-Undang Nomor 6 Tahun 2014 Tentang Desa. 